


\title{
Floods on Small Streams in North Carolina Probable Magnitude and Frequency
}

\author{
By Herbert G. Hinson
}

父

Prepared in cooperation with the North Carolina State Highway Commission

Geological Survey Circular 517 
United States Department of the Interior STEWART L. UDALL, Secretary

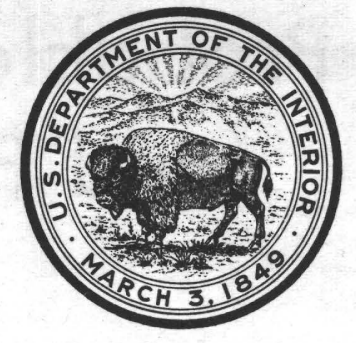

Geological Survey

William T. Pecora, Director 


\section{CONTENTS}

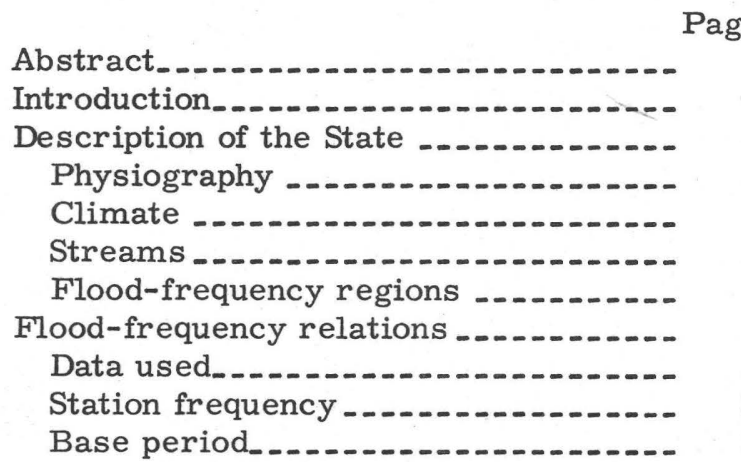

Flood-frequency relations-Continued

Page

The composite frequency curve..... 3

The mean annual flood............ 3

Drainage-area effect and the flood formula.

Geographic factor and the adjusted flood formula.

Application of the method ..........

Limitations ........

Selected references

3

1

2

2

2

\section{ILLUSTRATIONS}

Plate 1. Map of North Carolina showing flood-frequency regions and geographic

factors In pocket

Figure 1. Distribution of gaging stations used, by class of drainage-basin size
2. Composite frequency curves for flood-frequency regions $A$ and $B$

3. Nomograph for computing the mean annual flood 4 


\title{
Floods on Small Streams in North Carolina, Probable Magnitude and Frequency
}

\author{
By Herbert G. Hinson
}

\begin{abstract}
The magnitude and frequency of floods are defined regionally for small streams (drainage area, 1 to $150 \mathrm{sq} \mathrm{mi}$ ) in North Carolina. Composite frequency curves for each of two regions relate the magnitude of the annual flood, in ratio to the mean annual flood, to recurrence intervals of 1.1 to 50 years. In North Carolina, the mean annual flood $\left(Q_{2.33}\right)$ is related to drainage area $(A)$ by the following equation: $Q_{2.33}=G^{0.66}$, where $G$, the geographic factor, is the product of a statewide coefficient (115) times a correction which reflects differences in basin characteristics. Isograms of the $G$ factor covering the State are presented.
\end{abstract}

\section{INTRODUCTION}

The present report was prepared to amend and refine the flood-frequency relations given in previous reports. To assist design engineers and planners, several analyses were made from streamflow data available at the time and were released as reports on the magnitude and frequency of floods. Riggs (1955) prepared a flood-frequency report for North Carolina using streamflow records to October 1953. Forrest and Speer (1961) revised and extended the earlier analysis by Riggs, and presented in one volume the flood data collected to October 1960. Later floodfrequency reports (Speer and Gamble, 1964a, $1964 \mathrm{~b}, 1965)$ cover major river basins, each report being generally applicable to a part of North Carolina.

Application of the relations represented in the foregoing reports gives results which are generally reliable for streams that drain basins larger than about 150 square miles in North Carolina, but the more refined relationships in this report should, in general, give more reliable results for smaller basins. This refinement is possible because data from 120 crest-stage stations were used in the analysis. These stations, not used in previous analyses, were established during the period 1952-54 to gage peak flow from drainage basins mostly smaller than 50 square miles and to provide better geographic sampling.

The relatively short record from creststage gaging stations represents a minimum for flood-frequency analyses; however, this report is justified by the urgent need for flood-f requency information on small streams in North Carolina. Flood f requency on streams draining more than 150 square miles can be adequately determined by use of other floodfrequency reports (Speer and Gamble, 1964a, 1964b, 1965).

The methods of analysis and definitions used in this report are generally the same as those used in similar reports of the Geological Survey and are described by Dalrymple (1960).

This report was prepared in the Raleigh office of the U.S. Geological Survey under the direction of E. B. Rice, district engineer, Surface Water Branch, Water Resources Division, in cooperation with the North Carolina State Highway Commission, W. F. Babcock, director. The author was materially assisted in the analytical study and preparation of the report by G. C. Goddard, hydraulic engineer, of the Raleigh office of the Survey. Valuable technical guidance was given by A. Rice Green and $\mathrm{H}$. H. Barnes, Jr., hydraulic engineers, of the Washington office of the Survey.

\section{DESCRIPTION OF THE STATE}

\section{PHYSIOGRAPHY}

The physiographic divisions of the State fall into two broad categories (Fenneman, 
1946), the Atlantic Plain and the Appalachian Highlands. The Coastal Plain constitutes the Atlantic Plain of the eastern part of the State, and the Piedmont and Blue Ridge provinces constitute the southern Appalachian Highlands of the western part of the State. Boundaries between these divisions are not everywhere clearly defined, many falling in zones of transition. The boundaries are oriented in a general northeast-southwest direction, roughly parallel to the Atlantic coastline (pl. 1).

\section{Climate}

The climate of North Carolina is generally mild and humid but is the most varied of any Eastern State. The variations are due to differences in altitude and distance from the coast (Carney, 1960).

\section{STREAMS}

Stream basins of the State are within the larger drainage-basin systems of the United States, and each system forms an area termed a "part." These parts are the basis for divisions of reports on water supply of the United States into volumes. The three parts in North Carolina are Part 2-A (south Atlantic slope basins, James River to Savannah River), Part 3-A (Ohio River basin except Cumberland and Tennessee River basins), and Part 3-B (Cumberland and Tennessee River basins).

Although headwaters of principal streams of the Piedmont and mountains originate in the higher altitudes of the State, smaller streams originate in any locality. Streams originating in the Blue Ridge province and central and western areas of the Piedmont province have narrow valleys and steep slopes, whereas streams originating in the Coastal Plain and lower Piedmont provinces have wide valleys and flat slopes. The eastern part of the Coastal Plain, constituting about one-half this province, has swampy areas with very flat stream slopes.

\section{FLOOD-FREQUENCT REGIONS}

The State is divided into flood-frequency regions $A$ and $B(p l .1)$, within each of which the flood-producing characteristics are homogeneous. The division is based on a statistical test for homogeneity within each region.

\section{FLOOD-FREQUENCY RELATIONS}

\section{DATA USED}

The basic data used in this report are the records of annual maximum discharge collected at gaging stations operated by the Geological Survey and other agencies. Gaging stations in areas contiguous to North Carolina were used for complete areal coverage. Records from 257 gaging stations were used. These data are published in annual reports of the Geological Survey, and compilations have been made in several reports (Riggs, 1955; Forrest and Speer, 1961; Speer and Gamble, 1964a, 1964b, 1965). Streamflow records used in this report were restricted to gaging stations with less than 150 square miles of drainage area and with annual peaks for 5 or more years. Available records through the 1963 water year were used.

The basic data are fairly uniformly distributed with respect to geographic location, length of record, and drainage-area size. The longer records are generally from the Piedmont and Blue Ridge provinces; however, the collective records of the Coastal Plain province are considered sufficient for flood-frequency definition except for counties adjacent to the sounds (pl. 1). The distribution of gaging stations relative to drainage-area size is shown in figure 1.

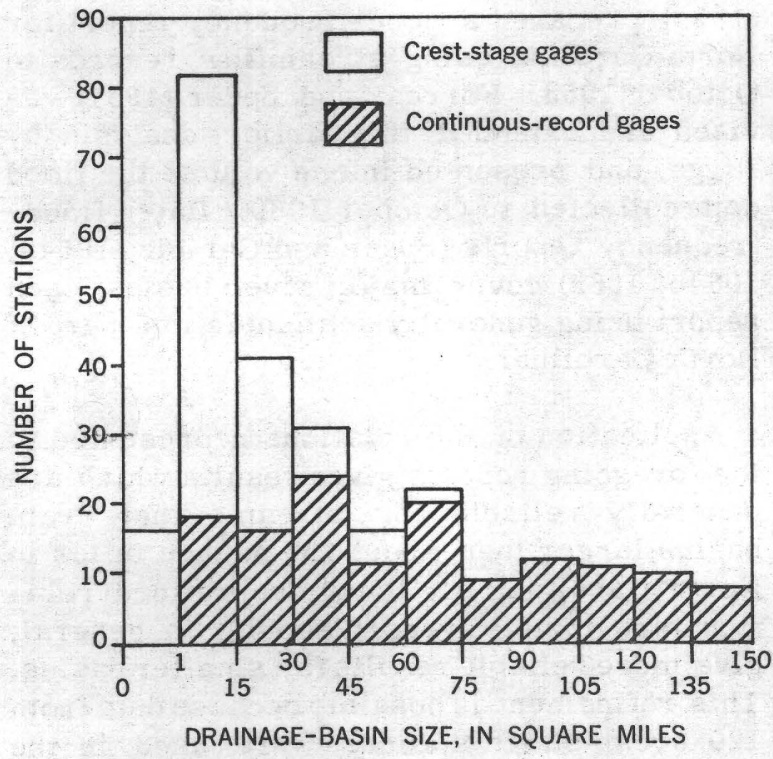

Figure 1. -Distribution of gaging stations used, by class of drainage-basin size 


\section{STATION FREQUENCY}

A flood-frequency relation defining the variation of annual peak discharge with recurrence interval was prepared for each station used. The flood-frequency relation for each station represents a statistical sample with respect to geography and time, and forms the basis for the regional analysis.

The flood-frequency relation for each gaging station was defined graphically by drawing a smooth curve through the plotted points for annual peak discharges on Gumbel logarithmic paper (Powell, 1943). The ordinate is the annual peak discharge and the abscissa is the recurrence interval.

The term "recurrence interval" is defined as the average interval of time within which a flood of a given magnitude is equaled or exceeded once. A flood with a recurrence interval of 25 years is the annual flood that is equaled or exceeded once in 25 years, on the long-term average. The concept implies no regularity in the time of recurrence of a given magnitude of flood. For example, floods having recurrence intervals of 25 years or greater might occur either in two consecutive years or at intervals much longer than 25 years. Another concept of frequency is in terms of probability. The probability of occurrence of a 25-year flood in any given year is 1 in 25 , or 0.04 .

\section{BASE PERIOD}

Because not all station records are the same length, and many are very short, any definite time period used for computation may result in a value that deviates significantly from the true mean. A base period of time common to all records or a period to which records can be extended is used in most analyses. In this study, however, no significant trend could be detected in a comparison of short-term versus long-term means for selected long-term stations representative of most areas of the State; hence, a base period was not used. A distinct advantage of using no base period is that all year of record, including historical floods, can logically be used.

\section{THE COMPOSITE FREQUENCY CURVE}

The station flood-frequency curve is only a sample at one particular site for a specific time period, and may not be representative of the long-term average flood experience for the general area. This is particularly true for frequency curves based on short records. Unfortunately, most streamflow records are considered short in a statistical sense (M. A. Benson, in Dalrymple, 1960, p. 5174). Because of the limitations of singlestation curves, a composite curve was defined for each of the two flood-frequency regions, $A$ and B. Each curve is applicable to all points in its respective region. The method is described by Dalrymple (1960).

In order for individual frequency curves to be combined, it was first necessary that they be expressed in comparable terms; therefore, discharges for selected recurrence intervals were expressed as ratios to the mean annual flood. The mean annual flood is defined as the flood corresponding to the 2.33-year recurrence interval.

The median ratio of discharge to the mean annual flood for each category of recurrence interval in each region was computed and plotted on Gumbel arithmetic paper to form the composite curve for that region. The composite curves for flood-frequency regions $\mathrm{A}$ and $\mathrm{B}$ are presented in figure 2.

The composite curve is applicable within a region to estimate flood-frequency relations for any site (drainage area, less than $150 \mathrm{sq}$ $\mathrm{mi})$, gaged or ungaged, not materially affected by manmade changes. Results from the use of the composite curve are considered generally more reliable than results from the use of individual station frequency curves, even for gaged sites.

\section{THE MEAN ANNUAL FLOOD}

The mean annual flood is a good measure of a drainage basin's flood characteristics and a good index of geographical variation of floodflow. Its magnitude is needed to apply the composite frequency curve. Because the topography of North Carolina is not completely mapped at scales suitable for special studies, many factors that might be used in a relation with the mean annual flood are not easily obtained and were not used in this report.

\section{DRAINAGE-AREA EFFECT AND THE FLOOD FORMULA}

The mean annual flood, as computed from gaging stations used in this study, ranges from 


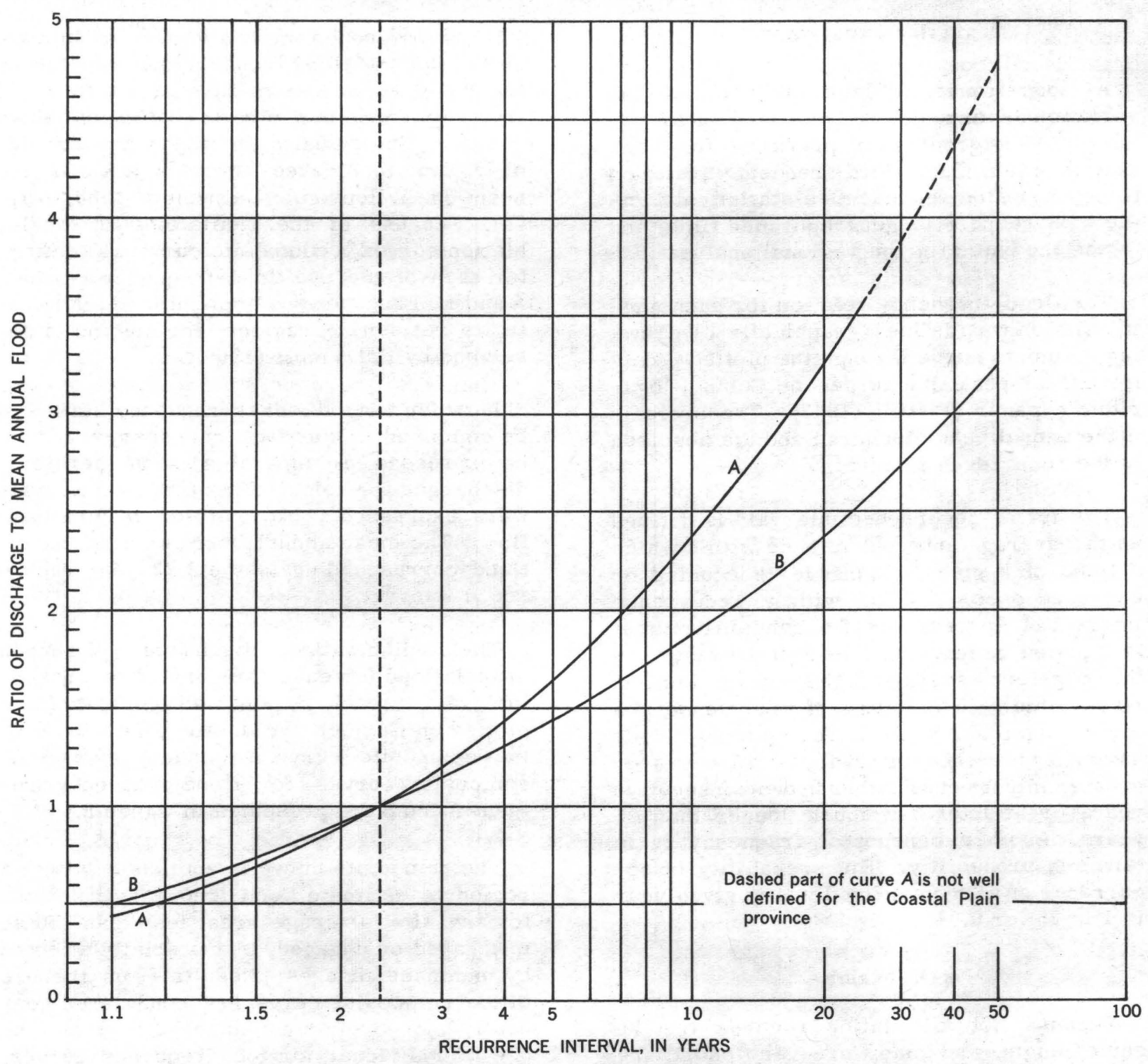

Figure 2.-Composite frequency curves for flood-frequency regions $A$ and $B$.

18.5 to $8,600 \mathrm{cfs}$ (cubic feet per second). The most important physical factor that causes this variation is basin size; the most appropriate measure of size is drainage area. The applicable relation of mean annual flood to drainage area is as follows:

$$
Q_{2.33}=115 A^{0.66}
$$

where

$Q_{2.33}=$ mean annual flood, in cubic feet per second, and

$A=$ drainage area, in square miles.

The mean-annual-flood formula is not to be applied in the form given above. Its adjustment is explained in the following section.

\section{GEOGRAPHIC FACTOR AND ADJUSTED FLOOD FORMULA}

The considerable scatter always found in plots showing the relation of drainage area to mean annual flood indicates that there are important physical factors, other than basin size, influencing the mean annual flood. These factors are described by Benson (1962). Estimates based on drainage area alone are, therefore, subject to considerable error. To refine the estimate and account for the other physical factors that affect floods, correction factors were computed as described below.

Values of mean annual floods as determined from station frequency curves were expressed 
as ratios to corresponding values of mean annual floods determined from equation 1 . Each ratio was multiplied by 115 , the coefficient in equation 1 . The resulting products were termed "geographic factors," and, when plotted at the middle of each respective drainage basin on the map, revealed the pattern of geographical distribution. Lines of equal value, interpolating and averaging station values of the geographic factor, are shown on plate 1. The interval between isograms of the geographic factor is normally 50 units. Dashed lines represent supplemental intervals of 25 units.

The adjusted formula for computing the mean annual flood, then, is

$$
\mathrm{Q}_{2.33}=\mathrm{GA}^{0.66}
$$

where

$Q_{2.33}=$ mean annual flood, in cubic feet per second,

$A=$ drainage area, in square miles, and

$\mathrm{G}=$ geographic factor.

\section{APPLICATION OF THE METHOD}

Detailed procedures are given below for determining the magnitudes of floods having recurrence intervals ranging from 1.1 to 50 years at sites having drainage areas between 1 and 150 square miles. The use of the nomograph shown in figure 3 is described for graphically solving equation 2 .

1. Ascertain that the selected site is not materially affected by manmade regulation or control, channel improvement, or extensive diversion of flood waters and that it is in an area where isograms are shown on plate 1.

2. Determine the drainage area, A, above the selected site. If the drainage area is between 1 and 150 square miles, proceed to step 3.

3. Locate the site on plate 1 and determine the flood-frequency region (A or B) in which the site is located.

4. From plate 1, determine the geographic factor, G, by locating the approximate center of the drainage basin for the site and estimating for this point the value of $G$ between adjacent isopleths. Estimation of $\mathrm{G}$ to closer than 10 units is unwarrented. (See limitations below.)
5. Determine the mean annual flood by use of the adjusted flood formula given in equation 2 and the values obtained from steps 2 and 4 . The formula can be solved graphically by use of the nomograph (fig. 3 ) by plotting the values of $A$ (step 2) and G (step 4) on those respective scales, connecting the plotted points with a straight line, and reading the mean-annual-flood discharge on the $Q$ scale.

6. From figure 2, use the appropriate curve ( $A$ or $B$ ) and determine the ratio of discharge to the mean annual flood for the selected recurrence interval.

7. Multiply the ratio obtained in step 6 by the mean annual flood obtained in step 5 to determine the peak discharge for the selected recurrence interval.

A complete recurrence-interval array can be compiled for a site by repeating steps 5, 6 , and 7 for several recurrence intervals.

\section{LIMITATIONS}

Of the many small streams in the State, those gaged afford a limited statistical sampling of the magnitude and frequency of floods. Average relations of streams having only natural flows are used. The relations for streams draining less than 1 square mile are not defined. Regional frequency curves cannot be extrapolated with confidence beyond 50 years, and composite flood-frequency curve A (fig. 2) is not well defined beyond 25 years in the Coastal Plain province because of the scarcity of long-term records for small streams in that province. Relations are not defined for certain areas along the coast and adjacent to the sounds.

Local influences on floods-such as regulation, urbanization, unusual geology, or ground cover-may not be represented by the average natural-flow condition of the streams used in the analysis. Special consideration is necessary for streams having predominant characteristics differing from those for the general area.

The geographic factor, $G$, is the composite value for the whole drainage basin. Plate 1 shows that these $G$ factors vary considerably within some basins, and it may be necessary to make allowances for these variations when estimating the appropriate value. 


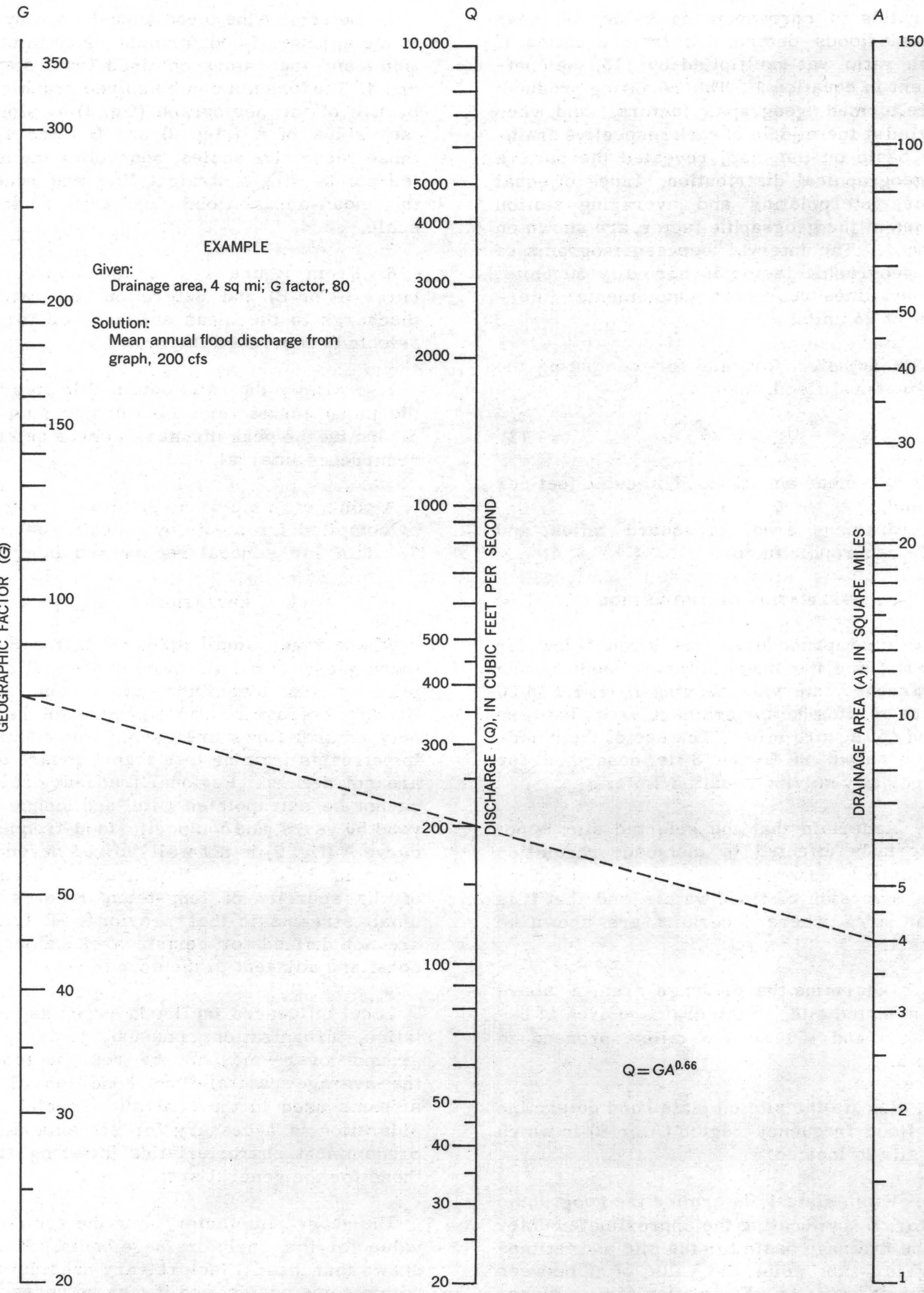

Figure 3. -Nomograph for computing the mean annual flood. 


\section{SELECTED REFERENCES}

Benson, M. A., 1950, Use of historical data in flood-frequency analysis: Am. Geophys. Union Trans., v. 31, p. 419-424.

-1962, Factors influencing the occurrence of floods in a humid region of diverse terrain: U.S. Geol. Survey WaterSupply Paper 1580-B, 64 p.

Bunch, C. M., and Price, McGlone, 1962, Floods in Georgia, magnitude and frequency: U.S. Geol. Survey open-file rept., $152 \mathrm{p}$.

Carney, C. B., 1960, Climates of the StatesNorth Carolina: U.S. Weather Bur. Climatography of United States, no. 60-31, $19 \mathrm{p}$.

Dalrymple, Tate, 1960, Flood-frequency analyses: U.S. Geol. Survey Water-Supply $\mathrm{Pa}-$ per $1543-\mathrm{A}, 80 \mathrm{p}$.

Fenneman, N. M., 1946, Physical divisions of the United States: U.S. Geol. Survey map.

Forrest, W. E., and Speer, P. R., 1961, Floods in North Carolina, magnitude and frequency: U.S. Geol. Survey open-file rept., 195 p.

Gumbel, E. J., 1941, The return period of flood flows: Annals Math. Statistics, v. 12, no. 2, p. 163-190.

Jenkins, C. T., 1960, Floods in Tennessee, magnitude and frequency: Tennessee Dept. Highways, $68 \mathrm{p}$.
Langbein, W. B., 1949, Annual floods and the partial-duration flood series: Am. Geophys. Union Trans., v. 30, p. 879-881.

Powell, R. W., 1943, A simple method of estimating flood frequencies: Civil Eng., v. 13 , no. 2 , p. 105-106.

Riggs, H. C., 1955, Floods in North Carolina, magnitude and frequency: U.S. Geol. Survey open-file rept., $59 \mathrm{p}$.

1961, Frequency of natural events: Jour. Hydraulic Div., Am. Soc. Civil Engineers Proc., v. 87, no. HY1, p. 15-26.

Speer, P. R., and Gamble, C. R., 1964a, Magnitude and frequency of floods in the United States, Part 2-A, South Atlantic slope basins, James River to Savannah River: U.S. Geol. Survey Water-Supply Paper 1673, 329 p.

1964b, Magnitude and frequency of floods in the United States, Part 3-B, Cumberland and Tennessee River basins: U.S. Geol. Survey Water-Supply Paper $1676,340 \mathrm{p}$.

1965, Magnitude and frequency of floods in the United States, Part 3-A, Ohio River basin except Cumberland and Tennessee River basins: U.S. Geol. Survey WaterSupply Paper 1675, 630 p. 